Kalynovskyi Bohdan,

Doctor of Sciences (Law),

National Academy of Internal Affairs, 1, Solomjanska Square, Kyiv, 03035, Ukraine

ORCID: 0000-0001-9654-0201

Kulyk Tetiana,

$\mathrm{PhD}$ (Law Sciences), Associate Professor,

National Academy of Internal Affairs,

1, Solomjanska Square, Kyiv, 03035, Ukraine

ORCID: 0000-0003-1720-1549

\title{
DECENTRALIZATION REFORM IN UKRAINE AS AN ELEMENT OF THE EUROPEAN VECTOR OF PUBLIC LAW DEVELOPMENT
}

The local public authority of a modern society is functioning within the limits of a certain territory and applies to the persons not on social (family, corporate, religious, etc.), but on a territorial basis. All entities subject to the relevant spatialgeographical unit determined by the legislation of the country must obey the said authority. In addition, the implementation of legal acts taken by local public authorities is due to the territorial boundaries of their activities.

The administrative-territorial system is the territorial basis of the organization of local public authorities, and at the same time it is the basis for its decentralization. Therefore, the issues of improving the administrative-territorial system are of particular importance in today's constitutional, municipal, budgetary, financial and administrative reforms. At the same time, it must be admitted that the current administrative-territorial system no longer responds to the political and socioeconomic challenges that have arisen in Ukraine. In order to form a constitutional decentralized state, the territorial basis of the organization of local public authority should be improved in the first place.

Key words: local government, local public authority, administrative-territorial system, decentralization, public power.

Калиновський Богдан, Кулик Тетяна. Реформа децентралізації в Украӥні, як елемент Свропейського вектора розвитку державного права.

Місиева державна влада сучасного суспільства функиіонує в межах певної території, $і$ здійснюється щяодо осіб не за соціальними (сімейними, корпоративними, релігійними тощо) ознаками, а на територіальній основі. Усі суб'єкти, щу підпадають під відповідну просторово-географічну одиницю, визначену законодавством країни, повинні підпорядковуватися зазначеним 
повноваженням. Крім того, реалізаиія нормативно-правових актів, прийнятих місиевими органами публічної влади, обумовлена територіальними межами їх діяльності.

Адміністративно-територіальна система є територіальною основою організації місиевих органів публічної влади і водночас є основою для ії децентралізачії. Тому питання вдосконалення адміністративно-територіальної системи мають особливе значення при здійсненні конституційної, муніџипальної, бюджетної, фінансової та адміністративної реформ. Водночас слід визнати, що нинішня адміністративно-територіальна система вже не відповідає на політичні та соціально-економічні виклики, що виникли в Украӥні. Для формування конституційно-децентралізованої держави в периу чергу слід вдосконалити територіальну основу організачії місиевої публічної влади.

Ключові слова: місиеве самоврядування, місцева влада, адміністративнотериторіальна система, децентралізація, публічна влада.

Relevance of the research topic. Considering the territorial basis for the organization of local public authority, above all, it makes sense to note that compared to the tribal organization of power, local public authority in modern society is functioning within a given territory and apply to subordinated entities not by social (family, corporate, religious, etc.) but on a territorial basis. The said authorities must obey all entities that are within the respective spatial and geographical unit designated by the law of the country. A territorial limit of the activity of local public authorities causes validness of legal acts which they adopt in this area.

At the same time, the peculiarities of the organization of local public authority depend to a large extent not only on the political and legal characteristics or level of professional training of employees, but also on the geographical characteristics of the territory concerned. "According to historical experience, it is noted in modern theoretical literature - the land itself, the territory of the state is the strategic resource, which, in significance, may prevail over all other resources» (1).

Formulation of the problem. The territorial basis of the organization of local public authorities is an important factor in its existence; it can contribute to and slow down the development of legislative regulation and practice of functioning of both local self-government and state authorities. The success of the decentralization reform depends to a large extent on the well-thought-out and functionally capable territorial basis of local public authority.

Analysis of recent research and publications. As we can notice authors in different ways studies aspects of local government, decentralization, arrangement of administrative-territorial structure, management of territories. For example G. Liddo, C. Magazzino, F. Porcelli in their work assess the relationship among government size, decentralization and economic growth in Italian ordinary regions. The result of research provides evidence in support of the existence of an inverted U-shaped 
relationship between public expenditure and economic growth, that depends on the degree of fiscal decentralization (2). Also, RonyEmmenegger dedicated research to contribute to an inherently political understanding of decentralization, development and their entanglement in local and national politics in rural African societies. Attention is payed to the fact, breaking with a centralized past, the incumbent government of the Ethiopian People's Revolutionary Democratic Front (EPRDF) committed itself to a decentralization policy in the early 1990s and has since then created a number of new sites for state-citizen interactions. But still decentralization has been interpreted as a means for the expansion of the party-state at the grass-roots level (3). This research proves that providing a decentralization policy sometimes takes long terms. Here in Ukraine we also have some challenges providing decentralization reform.

Presenting main material. The Constitution of Ukraine does not accidentally foresee Section IX «Territorial structure of Ukraine», which regulates and protects social relations in this area. Art. 132, 133 establish the rules of direct action regarding the basic principles of the formation of the internal territorial organization of the state. It is in accordance with the territorial structure of the state and the formation of state authorities and local self-government bodies, and therefore the local public authority is realized.

Researching the territorial basis of the organization of local public authority, it is also important to recall that the basic principles of the territorial structure of Ukraine are the following: the unity and integrity of the state territory; a combination of centralization and decentralization in the exercise of state power; balance and socioeconomic development of the regions taking into account their historical, economic, ecological, geographical and demographic characteristics, ethnic and cultural traditions.

The administrative-territorial division of Ukraine was formed in the 20's and 30 's of the 20th century without proper consideration of a set of factors, in particular the availability of resources, production potential, population density. The criterion for the formation of regions, districts, districts in the cities, among other things, was the number of members of the communist party within a certain territory. At the present stage of development of Ukraine in the reform of the administrative-territorial system must be taken into account historical, economic, ecological, geographical and demographic features, as well as ethnic and cultural traditions, which will ensure the balance and socio-economic development of communities and territories.

As already noted, the administrative-territorial system is the territorial basis of the organization of local public authority. In the context of this statement, it should be recalled that under the notion of «administrative-territorial system» is understood the system of internal territorial organization of the state due to geographical, historical, economic and other factors, which is enshrined in the law and is based on the division of the territory of the state into its constituent parts in order to ensure a balanced 
development of regions and a well-defined organization of the functioning of state authorities and local governments (4, p. 101).

In scientific sources, there is a definition of the notion of the territorial basis of local public authority, which is understood as the totality of elements of the system of the administrative-territorial structure of the state, within which the local public authority is functioning. It also includes a set of legal rules that establishes and regulates the territorial organization of local public authority, namely, the formation and composition of territories at the level of which local public authority is realized, the boundaries and status of these territories, the procedure for their establishment and change (5, p. 174].

Therefore, the elements of the administrative-territorial system of the state are an integral part of the territorial basis of local public authority. We must notice here, that the notion of territorial basis is wider - it includes the legal status of the territories, those from which territory is formed, the procedure for their establishment as one of the basis of local public authority, the procedure of defining the boundaries and making changes of the territory.

From the contents of Art. 118 of the Constitution of Ukraine it is understood that local state administrations exercise executive power in the regions and districts in the cities of Kyiv and Sevastopol (6). One of the peculiarities of the implementation of local public authority in the capital of Ukraine, in accordance with the Law of Ukraine «On the Capital of Ukraine Hero-City Kyiv» of January 15, 1999, is that the Kyiv City State Administration is the executive body of the Kyiv City Council and, accordingly, the local city state administration.

From 2001 to 2010, in Kyiv, in addition to the Kyiv City Council and its executive body - the Kyiv City State Administration, - there were ten district councils in Kyiv and their executive bodies - district administrations in Kyiv. Following changes to the Law of Ukraine «On the Capital of Ukraine Hero-City Kyiv» dated January 15, 1999, in 2010, by the decision of the Kyiv City Council «On the Issues of Organization of District Governance in the City of Kyiv» of September 9, 2010 No. 7/4819 (7) the activities (from October 31, 2010) were terminated by eliminating district administrations in the city of Kyiv and district administrations in Kyiv. By the order of the executive body of the Kyiv City Council (Kyiv city state administration) «On organizational and legal measures related to the implementation of the decision of the Kyiv City Council dated September 9, 2010 No. 7/4819» On the Issues of District Management in the City of Kyiv «of September 30 In 2010, No. 787(8), since October 31, 2010, district administrations have been formed in Kyiv, which are authorized by the order of the executive body of the Kyiv City Council (Kyiv city state administration) «On the implementation of district in Kyiv, by the state administrations of certain powers «from January 31, 2011, No. 121. (9) Consequently, the territorial basis for the implementation of local state administrations their power are the regions, districts, cities of Kyiv and Sevastopol and districts in these cities. 
Regarding the territorial basis of the implementation of local public authorities by the local self-government bodies, the Constitution of Ukraine states that local selfgovernment is the right of a territorial community - residents of a village or a voluntary association of residents of several villages into one village community, residents of a settlement, and of a city - for the purposes of an independent settlement of issues of local character in compliance with the Constitution and laws of Ukraine (Art. 140 of the Constitution of Ukraine). Local governments, representing the common interests of territorial communities of villages, towns and cities, are districts and region councils. Issues of organization of district management in cities fall within the competence of city councils.

It is well-known that according to the levels of organization of local selfgovernment, the system of administrative-territorial organization is divided into two main groups: settlements (cities, towns and villages) and territorial units (regions and districts). Settlements (cities, towns and villages) are the so-called «primary» level of local self-government, since only such territorial units form a fundamental element of the system of local self-government - a territorial community. Due to the lack of substantiation of the criteria for resettlement, a large number of settlements are rather conditionally assigned to urban or rural $(10,222)$.

Urban settlements in Ukraine include cities and towns of urban type, and rural include villages and towns. The basis of the division of settlements into urban and rural differences is the nature of material production, which significantly affects the size and location of settlements. If the development of urban settlements is associated with the capacity, specialization and placement of industrial enterprises, construction and transport facilities, then rural settlements with using land and location of agricultural production. For rural settlements it is also inherent a greater, compared with urban, remoteness from the places of work, close connection with the earth and the environment, etc. The main criterion for the selection of urban settlements is two features: the population (population) of the settlement and the proportion of workers, employees and members of their families in the total population. In general, the concept of «city» is understood as a populated place, significant in size, size and density of the population, employed mostly not in agrarian spheres of activity (10, p. 223).

According to state building codes «Urban planning. Planning and development of urban and rural settlements ", approved by the Decree of the State Committee of Ukraine for Urban Planning and Architecture of April 17, 1992, No. 44, provides the following typology of Ukrainian cities by population: small (up to 50 thousand people); average (50-250 thousand people); large (250-500 thousand people); significant or super-large (500 thousand-1 million people); major, or millionaire cities (over 1 million people) (11). 
The village as a form of settlement is inherent not only for the urban, but also for the rural population of Ukraine. The intermediate position between cities and rural settlements is occupied by urban-type settlements, which are considered as a reserve for replenishing the network of cities. Modern problems of rural settlement depend on the state's position on ways to solve peasant and land issues (12, p. 224).

Taking into account the experience of foreign countries, the content of the principle of subsidiarity and the adoption of a decentralization course by Ukraine, the city, the district in the city (with a population of more than 300 thousand people), the town, the village should be defined as the territorial basis for the implementation of local public authority by bodies of local self-government. We advocate a position according to which, if the number of inhabitants of the city is more than three hundred thousand, the city council is obliged to create areas in the city, as well as district councils in the city and their executive bodies. Therefore, we propose to make changes to Art. 5 of the Law of Ukraine «On Local Self-Government in Ukraine» dated May 21, 1997, with the provision of part 2 of Article 5 of this Law in the following wording: «In cities with a population of more than 300 thousand, the city council, by its decision in accordance with this Law, is required to form areas and district councils in the city. The number of residents in each district in the city should be at least 150 thousand inhabitants. In the formation of districts in the city and changing their boundaries, it is not allowed to establish a significant imbalance between the quality indicators for providing residents with municipal, administrative, social, cultural and other services. District councils in city councils form their executive bodies and elect the council chairman, who is also the chairman of its executive committee».

As already noted, Ukraine needs administrative and territorial reform to make sure the territorial basis of the organization of local public authority can satisfy the needs of the system of local public authorities. From the 1990s to the present, clarity and uniqueness of its implementation have not been achieved. In 1990, a draft law was proposed, in which it was intended to divide Ukraine into 13 regions which would have more powers. During 1997-1998 the work on the draft Law of Ukraine «On the administrative-territorial system of Ukraine» was actively pursued. The draft law was voted on October 16, 1997 by the Verkhovna Rada of Ukraine, but the President of Ukraine imposed a veto on him, which was not overcome (13).

It is worth mentioning also that in 2014 the parliament of Ukraine was discussed one more draft Law of Ukraine «On administrative-territorial system» registration number 319 . The bill aims to eliminate shortcomings in regulation of the issues of the administrative-territorial system (14). In fact, to establish boundaries had to be implemented the principle of universality and distribution of powers of local government in the territory outside the settlement. However, the relevant changes in the draft law are not proposed, there are no deadlines, within which there should be improvement of the territorial basis of the organization of local public authority. 
To date is the draft Law of Ukraine «On the Principles of the AdministrativeTerritorial Order of Ukraine» No. 8051 of 22.02.2018 (15), art. 4 of the draft Law determines that the system of administrative and territorial organization of Ukraine consists of the Autonomous Republic of Crimea, regions, districts, districts in the cities, cities, towns, villages, on the basis of which administrative- territorial units have to be formed.

The administrative-territorial units are regional, subregional, basic and auxiliary levels:the administrative-territorial units of the regional level (regions) are the Autonomous Republic of Crimea, the regions; the subregional level is the districts in the Autonomous Republic of Crimea and of the regions; the basic level is the communities that are formed on the basis of settlements (villages, towns, cities); auxiliary levels are the districts in cities.

Not new in the attempts to reform the administrative-territorial system, but the «new» in case of the adoption of the relevant law is the community as an administrative-territorial unit of the basic level, which includes one or several settlements. The community is a territorial basis for the implementation of local selfgovernment by residents of settlements located within the territory of the community, the formation and activities of local self-government bodies.

Immediately it strikes that the developers of the said Project are intended to carry out an administrative-territorial reform without introducing appropriate amendments to the Constitution of Ukraine, which contradicts Part 2 of Art. 8 of the Constitution of Ukraine.

One of the options for resolving the issue of the system of administrative and territorial system of Ukraine is contained in the Draft Law on Amendments to the Constitution of Ukraine (Regarding the Decentralization of Power) of July 1, 2015, No. 2217a. It provides for three levels of administrative-territorial organization, the special status of cities Kyiv and Sevastopol, regions and cities with a special status called the regions. According to the draft, the primary unit in the system of administrative-territorial organization of Ukraine is the community, and the procedure for the establishment, liquidation, establishment and change of borders, naming and renaming of communities, districts, regions, as well as the procedure for the creation, naming and renaming and assigning of settlements (villages, towns, cities) to the appropriate category are determined by law (16).

Conclusion. Therefore, we can conclude that the current model of the administrative-territorial system and, accordingly, the organization of local public authority, creates significant problems at the local level and needs an urgent solution. It seems that this can be fixed in two ways: the union of territorial communities or the allocation of territorial communities from other territorial communities. However this cannot be solved because of the absence of the Law of Ukraine on the territorial system. 


\section{REFERENCES}

1. Teoryia hosudarstva y prava [Tekst] : ucheb. dlia studentov vuzov. V. Ya. Liubashyts, A. Yu. Mordovtsev, Y. V. Tymoshenko, D. Yu. Shapsuhov ; predysl. S. A. Komarova. Moskva; Rostov na Donu : YTs «MarT», 2003. S. 77.

2. Giuseppe Di Liddo, Cosimo Magazzino \& Francesco Porcelli Government size, decentralization and growth: empirical evidence from Italian regions.Taylor and Francis Online. 2017 p. 2777-2791. URL: https://www.tandfonline.com/doi/full/ 10.1080/00036846.2017.1409417 01.08.2018.

3. Rony Emmenegger Decentralization and the local developmental state: peasant mobilization in Oromiya, Ethiopia. 2016. pp. 263-287. URL: https://doi.org/ 10.1017/S0001972016000048 01.08.2018.

4. Vermenych Ya. V. Terytorialna orhanizatsiia $\mathrm{v}$ Ukraini yak naukova problema: rehionalno-istorychnyi ta polityko-administratyvnyi vymiry. Kyiv, 2008. S. 101.

5. Atamanchuk H. V. Teoryia hosudarstvennoho upravlenyia : kurs lektsyi. H. V. Atamanchuk. Moskva : Yuryd. lyt., 1997. S. 174.

6. Konstytutsiia Ukrainy : chynne zakonodavstvo zi zminamy ta dopovnenniamy stanom na 30 veres. 2016 r. : (OFITs. TEKST). Kyiv. : PALYVODA A. V., 2016. $76 \mathrm{~s}$.

7. Pro pytannia orhanizatsii upravlinnia raionamy v misti Kyievi: rishennia Kyivskoi miskoi rady vid 9 veresnia 2010 roku № 7/4819. Khreshchatyk : hazeta Kyivskoi miskoi rady. 2010. URL: http://kreschatic.kiev.ua/doc/1284052871.html (data zvernennia 24.01.2015).

8. Pro pytannia orhanizatsii upravlinnia raionamy v misti Kyievi: rozporiadzh. vykonavchoho orhanu Kyivskoi miskoi rady (Kyivskoi miskoi derzhavnoi administratsii) vid 30 veresnia 2010 r. № 787. URL: http://dnipr.kievcity.gov.ua/ files/docs/org_prav_zah.pdf (data zvernennia 24.01.2015).

9. Pro realizatsiiu raionnymy $v$ misti Kyievi derzhavnymy administratsiiamy okremykh povnovazhen : rozporiadzh. vykonavchoho orhanu Kyivskoi miskoi rady (Kyivskoi miskoi derzhavnoi administratsii) vid 31 sich. 2011 r. № 121. Khreshchatyk : hazeta Kyivskoi miskoi rady. 2011 URL : http://kreschatic.kiev.ua/doc/1298576040. html (data zvernennia 24.01.2015).

10. Zahalni zasady mistsevoho samovriaduvannia $v$ Ukraini : pidruch. [avt.uporiad. : O. V. Batanov, N. M. Batanova, V. M. Vakulenko ta in.] ; za zah. red. V. M. Vakulenka, M. K. Orlatoho. K. : NADU, 2010. S. 222 
11. Mistobuduvannia. Planuvannia i zabudova miskykh i silskykh poselen DBN 360-92. Nakaz Derzhavnoho komitetu Ukrainy u spravakh mistobuduvannia i arkhitektury vid 17 kvitnia 1992 roku № 44. URL: http://www.uazakon.com/ documents/date_3v/pg_gnglwj/index.htm/ (data zvernennia: 02.05.2018).

12. Zahalni zasady mistsevoho samovriaduvannia v Ukraini : pidruch. / [avt.uporiad. : O. V. Batanov, N. M. Batanova, V. M. Vakulenko ta in.] ; za zah. red. V. M. Vakulenka, M. K. Orlatoho. K. : NADU, 2010. S. 224.

13. Proekt Zakonu Ukrainy «Pro administratyvno-terytorialnyi ustrii Ukrainy» vid 8 lypnia 1997 roku URL: http://w1.c1.rada.gov.ua/pls/zweb2/webproc4_1? pf3511=2111 (data zvernennia: 02.05.2018).

14. Vysnovok Naukovo-ekspertnoho upravlinnia aparatu Verkhovnoi Rady Ukrainy na proekt Zakonu «Pro administratyvno-terytorialnyi ustrii» (reiestr. № 3373 vid 30.10.2013) URL: http://w1.c1.rada.gov.ua/pls/zweb2/webproc4_1?pf3511= 48586/ (data zvernennia: 02.05.2018).

15. Proektu Zakonu Ukrainy «Pro zasady administratyvno-terytorialnoho ustroiu Ukrainy». URL: http://w1.c1.rada.gov.ua/pls/zweb2/webproc4_1?pf3511= 63508 (data zvernennia: 02.05.2018).

16. Proekt Zakonu pro vnesennia zmin do Konstytutsii Ukrainy (shchodo detsentralizatsii vlady) : proekt Zakonu vid 1 lypnia 2015 roku № 2217a URL: http://w1.c1.rada.gov.ua/pls/zweb2/webproc4_1?pf3511=55812 (data zvernennia: 02.05.2018). 